\title{
Desain Interior KM Kelimutu sebagai Kapal Wisata dengan Nuansa Budaya Indonesia Timur yang Modern
}

Abstrak-Indonesia memiliki kekayaan obyek wisata bahari di wilayah taman laut. Selain itu juga didukung oleh 263 jenis Moch. Ilham Fahma dan Thomas Ari Kristianto

Departemen Desain Interior, Fakultas

Arsitektur Desain dan Perencanaan, Institut Teknologi Sepuluh Nopember (ITS)

e-mail: thomasjawa@prodes.its.ac.id

yang sangat melimpah dan diminati oleh wisatwan domestic mau pun mancanegara. Pada tahun 2014, 30\% dari 9,4 juta wisatawan mancanegara yang berkunjung, merupakan wisatawan bahari. Tiap tahun jumlah selalu meningkat dengan dipermudahnya akses kapal pesiar asing berlayar di laut Indonesia untuk melakukan wisata bahari. Potensi ini dinilai PT Pelni selaku perusahaan kapal terbesar di Indonesia sebagai prospek yang menjanjikan dalam dunia pariwisata Indonesia, khususnya bahari. Mengingat belum adanya kapal pesiar milk dalam negeri, PT Pelni berencana untuk memodifikasi KM Kelimutu sebagai kapal pesiar dengan rute menuju Indonesia timur meliputi Bali, Kepulauan Nusa Tenggara, Maluku dan Papua. Berdasarkan rute yang ditentukan, desain interior yang mengusung budaya Indonesia timur dinilai cocok untuk diterapkan untuk lebih mengenalkan kebudyaan dan objek wisata yang akan dikunjungi. Elemen interior yang ada pada kapal tentu berbeda dengan bangunan daratan. Material yang diterapkan harus mengikuti regulasi yang ada pada kapal untuk keamanan dan kenyaman penumpang. Dengan mempertimbangkan aspek budaya dan regulasi, diharapkan interior yang didesain dapat memberikan keamanan dan kenyamanan penumpang. Selain itu, diharapkan karya Studi ini dapat dijadikan referensi dalam dunia interior kapal di Indonesia.

Kata Kunci-Wisata Bahari, Kapal Motor, Indoneisa Timur, Material.

\section{PENDAHULUAN}

$\mathrm{P}$ T Pelayaran Nasional Indonesia merupakan perusahan berskala nasional yang menyediakan jasa transportasi laut, baik melayani jasa angkutan penumpang dan juga muatan barang antar pulau. Pelni meliputi wilayah Indonesia yang dikenal dengan negara dengan memiliki wilayah laut yang sangat luas. Panjang garis pantai Indonesia mencapai $95.181 \mathrm{~km}$ (World Resources Institute, 1998) dengan luas wilayah laut 5,4 juta kilo meter persegi dari total luas teritorial Indonesia sebesar 7,1 juta kilo meter persegi.

Indonesia juga memiliki potensi pariwisata bahari yang memiliki daya tarik bagi wisatawan. Selain itu juga potensi tersebut didukung oleh kekayaan alam yang indah dan keanekaragaman flora dan fauna. Misalnya, kawasan terumbu karang di seluruh Indonesia yang menurut data Badan Pusat Statistik luasnya mencapai $7.500 \mathrm{~km}^{2}$ dan umumnya terdapat ikan hias di sekitar terumbu karang, biota langka dan dilindungi (ikan banggai cardinal fish, penyu, dugong, dll), serta migratory species. Hal ini meningkatkan pentingnya Budaya Indonesia khususnya pada era modern ini dibidang maritim atau laut untuk lebih digali potensinya.

Armada kapal adalah armada yang memiliki peran penting dalam jasa transportasi laut. Menurut pasal 309 KUHD (Kitab Undang-Undang Hukum Dagang), disebutkan bahwa kapal adalah semua alat berlayar, bagaimanapun namanya dan apapun sifatnya. Kecuali bila ditentukan lain, atau diadakan perjanjian lain, dianggap bahwa kapal itu meliputi perlengkapan kapalnya.

Berdasarkan data internal PT Pelni saat ini, PT Pelni memiliki armada kapal yang akan memasuki masa-masa habis usia ekonomisnya. Dari 29 armada, 1 unit berusia kurang dari 10 tahun, 11-15 tahun sebanyak 3 unit, 8 unit berusia antara 16-20 tahun dan paling banyak berusia antara 21-25 tahun sebanyak 11 unit. Berdasarkan pertaturan Departemen Perhubungan, batas umur kapal beroperasi adalah 25 tahun [1].

Dengan cukup banyaknya armada yang memilki usia lebih dari 20 tahun, PT Pelni memiliki dua pilihan. Yang pertama yaitu scrapping, yaitu penghancuran kapal yang telah tidak digunakan, dan yang kedua yaitu penigkatan kualitas armada kapal. Melihat potensi wisata bahari dalam negeri yang tengah digemari beberapa tahun terakhir, PT Pelni memilih opsi dengan meningkatkan kualitas armada kapalnya menjadi kapal pesiar yang memiliki rute dalam negeri. PT Pelni bekerja sama dengan ITS untuk memodifikasi salah satu armada kapalnya yaitu KM Kelimutu. Dalam mendesain sebuah kapal, perlu diperhatikan utilitas eksisting kapal dan unsur penting lainnya seperti pemilihan material. Banyak batasan yang ada dalam mendesain sebuah interior kapal antara lain yaitu memenuhi segala standar keamanan dalam kapal, luasan ruangan yang sangat terbatas sehingga perlu diperhatikannya tata letak furnitur dan bentuk furniture [2].

Rute yang dilewati KM Kalimutu yaitu rute menuju Indonesia bagian timur dari Bali, Nusa Tenggara, Sulawesi, Maluku dan Papua. Maka dari itu, konsep yang digunakan untuk menunjang peningkatan kualitas armada kapal menjadi kapal pesiar dengan rute tersebut, yaitu dengan mengangkat konsep yang berhubungan dengan tujuan destinasi melalui pengenalan budaya Indonesia timur baik dalam pengenalan motif, binatang endemik dan pemilihan warna, motif serta corak dengan dipadukan unsur modern. 


\section{A. Tujuan}

1) Tercapainya desain interior yang memadukan ciri khas visual dari beberapa budaya di Indonesia Timur.

2) Terdesainnya fungsi ruang yang baik sesuai dengan standar.

3) Terdeskripsinya standar kapal dalam aplikasi desain.

\section{B. Manfaat}

1) Sebagai referensi desain PT Pelni untuk proyek lainnya.

2) Detail desain untuk bangunan transportasi atau kapal.

\section{Rumusan Masalah}

1) Bagaimana pengaplikasian desain interior yang dapat mencerminkan daerah-daerah dari Indonesia Timur.

2) Bagaimana mendesain fungsi ruang yang baik/normal dalam kapal dengan kondisi yang ada pada kapal.

3) Bagaimana material standar yang akan digunakan dalam mendesain interior KM Kelimutu.

Berdasarkan rumusan masalah diatas, maka lingkup permasalahan berfokus pada bagaimana mendesain interior sebuah kapal pesiar PT. Pelni sehingga dapat mencerminkan budaya Indonesia Timur dengan tidak mengurangi nilai fungsional dan pemilihan standar material yang digunakan dalam interior kapal.

\section{METODOLOGI PENELITIAN}

Penelitian ini dilakukan melalui beberapa metode. Gambar 1 menjelaskan urutan metodologi penelitian.

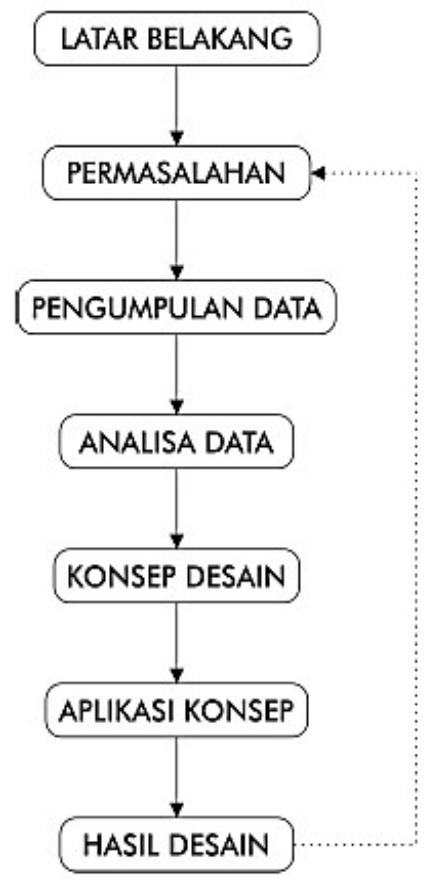

Gambar 1. Metodologi penelitian.

Sumber: Dokumentasi Penulis (2018)

Bagan di atas menjelaskan bagaimana konsep desain didapatkan setelah melalui berbagai tahapan. Hal yang pertama dilakukan yaitu menentukan obyek desain yang akan dilakukan riset pada latar belakang kemudian setelah obyek desain ditentukan, dimulai dengan mengetahui permasalahan pada obyek desain dan dilanjutkan ke metode pengumpulan data.

Langkah selanjutnya adalah mengumpulkan data berdasarkan masalah dan tujuan yang telah diperoleh sebelumnya. Pengumpulan data ini dibagi menjadi 2 jenis, yaitu:

1) Data primer, berupa hasil wawancara, dan observasi.

2) Data sekunder, berupa hasil studi literatur dan studi pembanding.

Setelah mendapatkan data yang dibutuhkan, dilakukan analisa terhadap data tersebut untuk menghasilkan rumusan konsep desain. Konsep ini perlu untuk ditinjau kembali apakah sesuai dengan tujuan dan telah menjawab permasalahan yang muncul sebelumnya.

Metode yang digunakan adalah dengan memecahkan masalah yang ada dengan menggunakan beberapa metode, yaitu:

1) Observasi

Observasi merupakan pengamatan suatu obyek atau hal secara langsung. Teknik observasi yang dilakukan adalah dengan melakukan kunjungan ke kantor head project untuk medapatkan data-data yang diperlukan dan saran-saran yang sebaiknya dilakukan dalam perancangan. Tujuan dari observasi adalah untuk mengetahui permasalahan dari sudut pandang pemilik KM Kelimutu.

a) Wawancara

Narasumber dalam wawancara ini adalah head project dari proyek KM Kelimutu. Wawancara dilakukan untuk mendapat informasi yang jelas mengenai $\mathrm{KM}$ Kelimutu. Tujuan dari wawancara adalah untuk mengetahui permasalahan dari sudut pandang desainer KM Kelimutu dan arahan desain yang diberikan sesuai dengan karakter yang diinginkan pemilik dan tujuantujuannya.

b) Studi Literatur

Studi Literatur merupakan studi dengan mencari sumber referensi baik teori maupun ide yang relevan melalui buku, jurnal, artikel, dan situs internet.

Metode analisis data yang digunakan adalah metode deskriptif kualitatif dan deskriptif kuantitatif. Metode deskriptif kualitatif diterapkan pada analisis data wawancara. Adapun analisis yang berkesesuaian dengan hasil observasi seperti analisis konsep desain, kebutuhan ruang, ergonomi dan pengguna dijelaskan dengan metode deskriptif. 


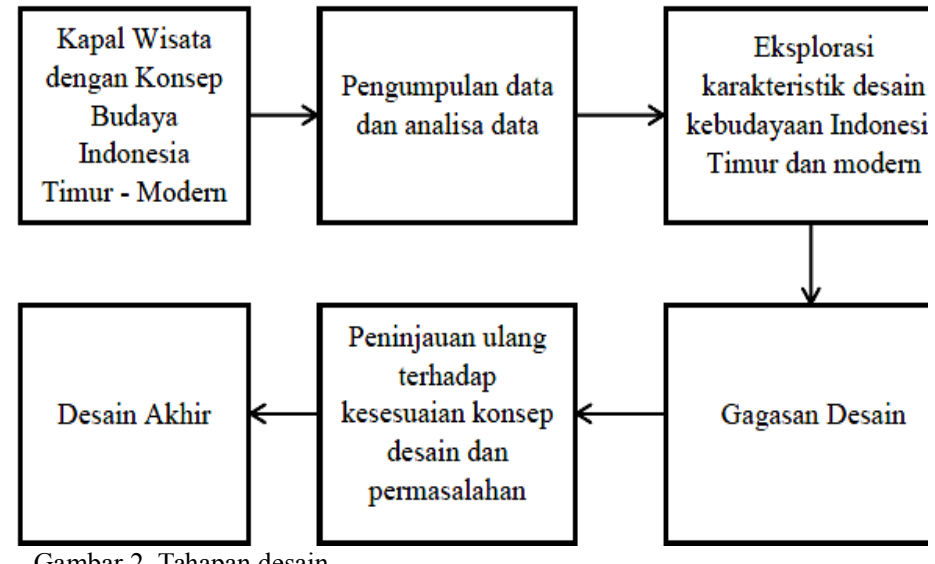

Gambar 2. Tahapan desain.

Sumber: Dokumentasi Penulis (2018)

Tahapan desain dibutuhkan dalam merancang desain yang akan dibuat melalui proses visualisasi konsep desain interior. Pada tahapan ini, proses perancangan gagasan-gagasan ide yang diperoleh melalui penggalian data, tahap analisa data dan tahapan lainnya.

\section{KONSEP DESAIN}

Berikut ini merupakan pengaplikasian konsep budaya Indonesia timur yang modern untuk KM Kalimutu:

\section{A. Konsep Lantai}

Pada runag tinggal/kamar, akan menggunakan Pada lantai menggunakan marine flame retardant PVC flooring dengan motif parket. Area restoran juga menggunakan lantai tersebut, tetapi juga dipadukan dengan lantai keramik bermotif sebagai variasi pada beberapa spot tertentu. Penggunaan lantai dengan motif parket bertujuan untuk memberikan kesan hangat dan alami pada ruangan. Selain itu, suasana interior yang dipadukan dengan kebudayaan dari suku-suku yang ada di wilayah Indonesia timur dirasa lebih berkarakter jika dipadukan dengan material berbahan atau bermotif kayu.

Ruang tinggal dan restoran menggunakan plint lantai yang langsung tersambung dengan lantai. Tidak seperti pada umumnya yang membentuk siku, plint ini membentuk lengkungan sehingga lebih mudah saat dibersihkan. Sedangkan pada ruang rapat, lantai menggunakan material karpet dengan warna krem. Penggunaan karpet bertujuan untuk meredam suara/sebagai akustik.

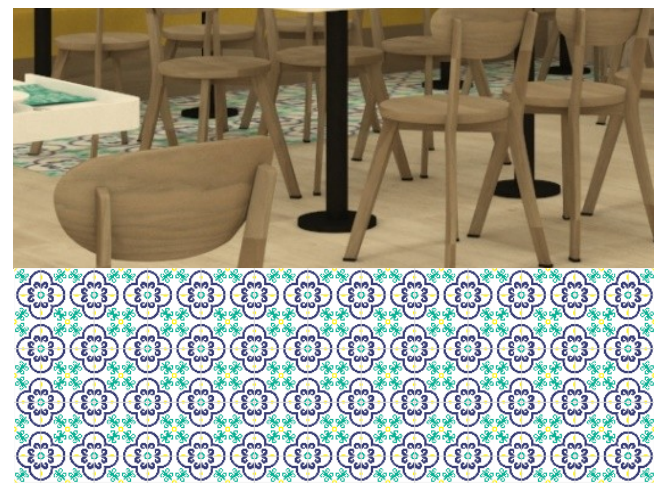

Gambar 3. Lantai parket dan lantai keramik bermotif.

Sumber: Dokumentasi Penulis (2018)

\section{B. Konsep dinding}

Pada ruang tinggal, dinding yang digunakan berupa wallpaper dengan motif kain Bali. Sedangkan ruang rapat menggunakan wallpaper polos. Pada salah satu sisi dinding menggunakan wallpaper yang berisikan infografis peta UNESCO Indonesia yang menunjukkan objek-objek wisata yang telah menjadi warisan dunia, tentunya sangat direkomendasikan untuk dikunjungi. Area restoran juga menggunakan wallpaper polos, tetapi dipadukan dengan wallpaper bermotif kayu setinggi 1 meter yang ditambahkan motif Asmat (Gambar 4).

\section{Konsep plafon}

Konsep plafon yang diterpkan akan disesuaikan dengan fungsi ruang. Ruang privat (kamar tinggal) menggunakan plafon yang polos. Selain karena sempitnya ruang dan rendahnya plafon pada kapal, plafon polos akan memberikan suasana yang lebih tenang. Pada area restoran juga akan menggunakan plafon polos. Sedangkan pada ruang rapat, menggunakan drop ceiling dengan tambahan motif khas Suku Asmat.

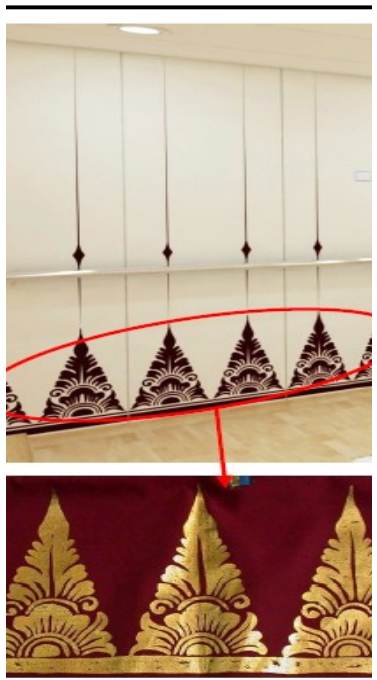

Gambar 4. Wallpaper dengan motif Bali.

Sumber: Dokumentasi Penulis (2018)

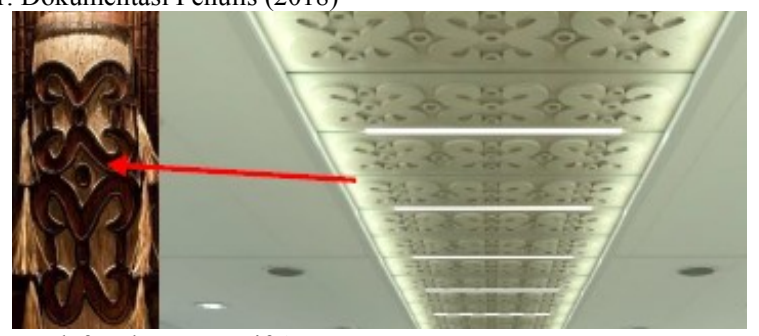

Gambar 5. Plafon dengan motif Asmat.

Sumber: Dokumentasi Penulis (2018)

\section{Konsep furnitur.}

Furnitur yang digunakan menggunakan bentuk yang simple yang dipadukan dengan corak budaya. Selain itu, juga akan menggunakan furnitur hasil dari transformasi bentuk dari motif/benda-benda budaya. Pada kamar tinggal, furnitur yang digunakan memiliki bentuk yang simpel dan memiliki motif kain Bali. Ruang rapat dan area restoran juga memiliki furnitur simpel dengan tambahan motif Suku Asmat pada ruang rapat, sedangkan area restoran hanya menggunakan furnitur tanpa motif suku. Namun, tidak semua furnitur yang 
digunakan pada setiap ruang memiliki motif, tetapi disesuaikan dengan komposisi tema pada ruangan.
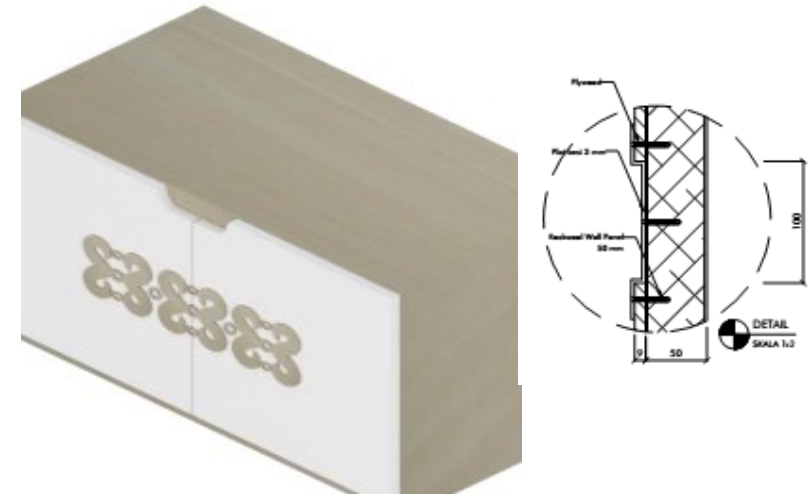

Gambar 6. Furnitur dengan Motif Asmat dan detail pemasangan.

Sumber: Dokumentasi Penulis (2018)

Untuk furnitur yang memiliki posisi yang tetap (bed, meja, dan sejenisnya), peletakannya dipermanenkan dengan cara disekrup pada lantai, untuk mengantisipasi adanya goncangan pada kapal agar tidak berpindah. Sedangkan furnitur yang fleksibel penempatannya seperti kursi, menggunakan karet pada bagian alas untuk meminimalisir slip pada saat kapal terguncang. Khusus untuk meja makan, menggunakan "lidah" pada sisi meja dengan lubang pada salah satu ujung. Tujuannya untuk mengantisipasi alat makan dan minum pada saat kapal terguncang.
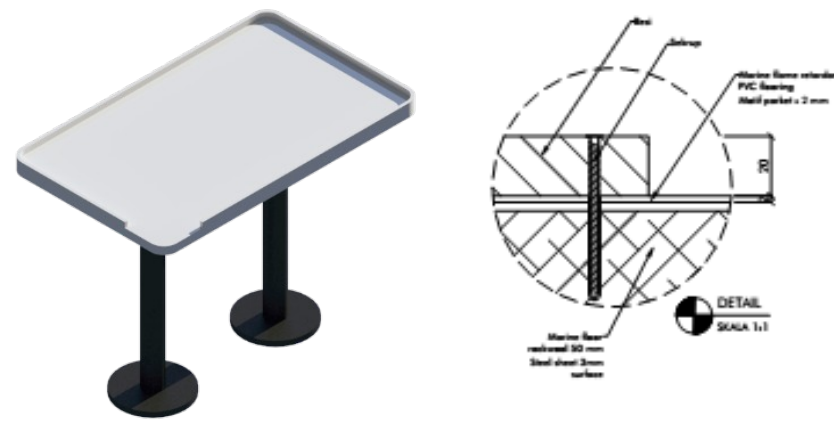

Gambar 7. Meja Makan dan detail pemasangan.

Sumber: Dokumentasi Penulis (2018)

\section{E. Konsep elemen estetis}

Penambahan elemen estetis tidak diterapkan pada seluruh ruangan, akan tetapi hanya digunakan pada area atau ruang yang memang diperlukan.

Elemen estetis akan ditempatkan pada ruang hiburan atau umum seperti restoran dan ruang tinggal. Ukuran elemen estetis disesuaikan dengan bidang yang akan dipakai, sedangkan bentukan dan motif diambil dari kebudayaan sukusuku yang ada di wilayah Indonesia bagian timur.

Budaya dari suku Indonesia bagian timur yang akan diterapkan contohnya yaitu suku Asmat dan suku Bali, baik dalam segi corak, tarian, warna, serta hewan endemik atau hewan khas yang berasal dari Indonesia timur.
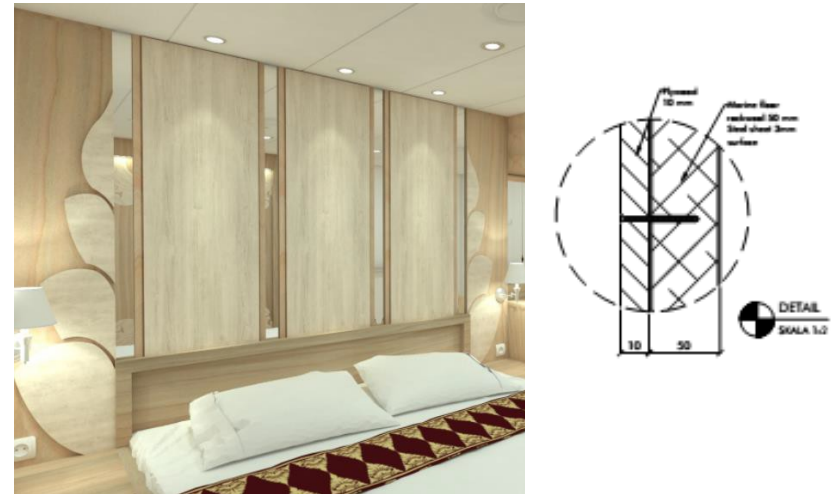

Gambar 8. Headbed dan detail pemasangan.

Sumber: Dokumentasi Penulis (2018)

Pada bagian ruang tinggal atau kamar, elemen estetis diletakkan di atas tempat tidir, sehingga juga dapat difungsikan sebagai headbed.

Elemen estetis ini berupa headbed dengan material multiplek gapura Bali yang ditransformasikan atau diolah lagi dari segi bentuk menjadi lebih sederhana. Pada bagian dinding TV ditambahkaan elemen estetis bermaterial multiplek dengan motif ukiran khas Bali. Untuk memudahkan perawatan, motif panorama pura dan ukiran dibuat dengan teknik cetak print atau printing wallpaper, sehingga mudah dalam maintenance atau pemeliharaan dalam jangka waktu pendek dan panjang dibandingkan dengan menggunakan teknik $\mathrm{CNC}$ atau ukir.

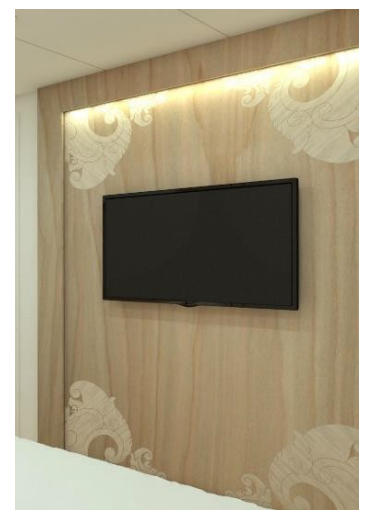

Gambar 9. Elemen estetis dinding TV.

Sumber: Dokumentasi Penulis (2018)

Sedangkan pada restoran, elemen estetis diletakkan pada dinding. Elemen estetis pertama berupa siluet tarian Suku Asmat yang ditempatkan di bagian tengah. Sedangkan di bagian samping kanan dan kiri menggunakan aksen garis-garis yang membentuk gelombang bermaterial kayu dengan sedikit sentuhan warna kuning dan tosca.

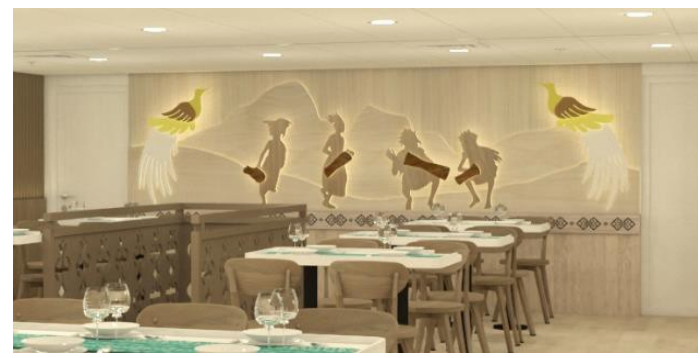

Gambar 10. Elemen estetis siluet tarian Asmat. 
Sumber: Dokumentasi Penulis (2018)

\section{F. Konsep pencahayaan}

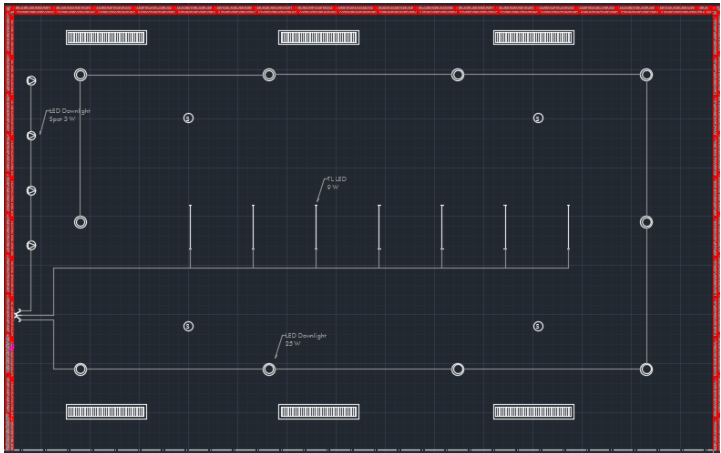

Gambar 11. Penempatan downlight dan lampu TL pada ruang rapat. Sumber: Dokumentasi Penulis (2018)

Pencahayaan yang digunakan adalah pencahayaan alami dan buatan. Tetapi, ukuran jendela yang tidak terlalu besar dan jumlah yang terbatas pada beberapa ruang, harus ditunjang dengan penggunaan pencahyaan buatan. Pada ruang tinggal dan area rstoran, menggunakan downlight sebagai pencahyaan general. Untuk menambahkan kesan hangat pada area restoran, ditambahkan wall lamp pada sisi bagian kapal sekaligus untuk menunjang suasana ketika malam hari. Sedangkan di ruang rapat, menggunakan 2 jenis lampu yaitu downlight pada bagian sisi ruangan dan lampu TL pada bagian tengah.

\section{G. Konsep warna}

Warna yang digunakan adalah warna-warna yang diambil berdasarkan warna-warna kain atau pun benda lainnya pada kebudayaan suku-suku Indonesia timur. Selain itu, juga aditambahkan suasana hangat untuk menyelaraskan warnawarna yang beragam, sehingga akan lebih serasi pada suatu ruangan dengan penggunaan warna atau motif kayu alami. Pada ruang tidur, menggunakan warna maroon sebagai warna aksentuasinya, sedangkan pada ruang rapat menggunakan warna biru navy. Warna yang diambil berdasarkan warna kain pada masing-masing suku, dan area restoran menggunakan warna tosca dan kuning sebagai warna aksentuasi.

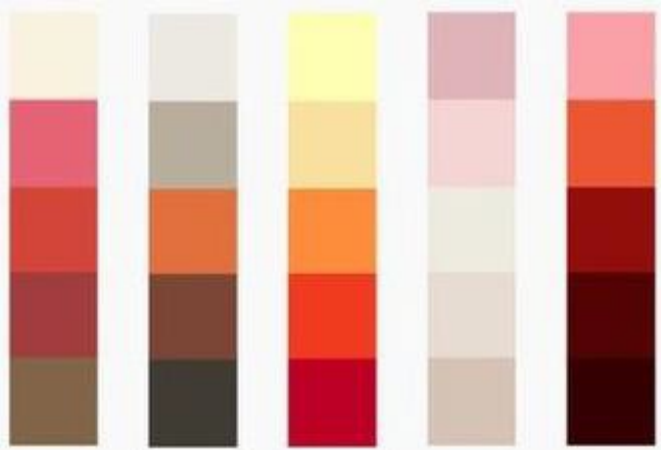

Gambar 12. Diagram warna hangat atau warm color. Sumber: https://www.pinterset.co.uk/pin/552394710528455773/
IV. HASIL DAN PEMBAHASAN

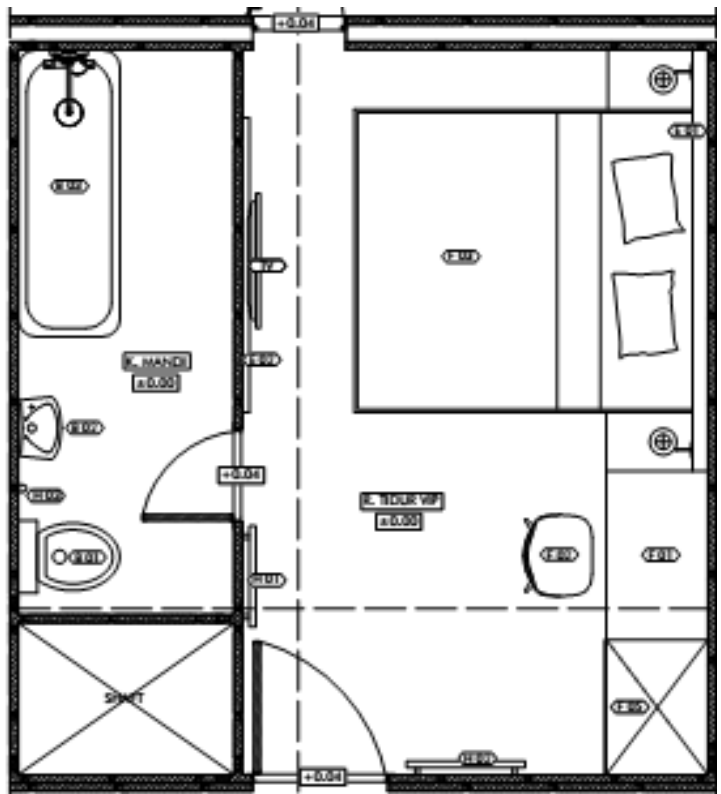

Gambar 13. Layout ruang terpilih 1 atau ruang kamar VIP

Sumber: Dokumentasi Penulis (2018)

Pemilihan konsep dengan mengangkat budaya Indonesia timur dan konsep modern baik dalam pemilihan material maupun estetika dapat menciptakan suasana yang berbeda. Ciri khas masyarakat Indonesia tmur yang berbeda dengan bagian Indonesia lainnya dihadirkan melalui pemilihan tone warna hangat dan keanekaragaman budaya setempoat seperti tarian serta bentukan dari setiap daerah yang diatur sedemikian rupa sehingga dapat menghadirkan konsep berkesinambungan dan seimbang yang optimal.

Pada ruang kamar VIP terdapat bed dengan kapsitas 2 orang dengan disampingnya terdapat meja kerja dan almari. Kamar mandi berada di hadapnya. Pada sisi dinding terdapat railing untuk pegangan jika terjadi guncangan yang cukup kuat. Material dinding yang digunakan yaitu rockwool wall panel yang terdiri dari 2 bagian, yaitu bagian inti dan permukaan. Intinya berisi rockwool dan permukaannya berupa aluminium dengan tebal total $50 \mathrm{~mm}$. Sedangkan atap menggunakan aluminium honeycomb ceiling panel dengan inti berupa aluminium honeycomb dan permukaan aluminium. Pada lantai menggunakan marine flame retardant PVC flooring dengan motif parket. Material ini memiliki spesifikasi tahan api dan air.

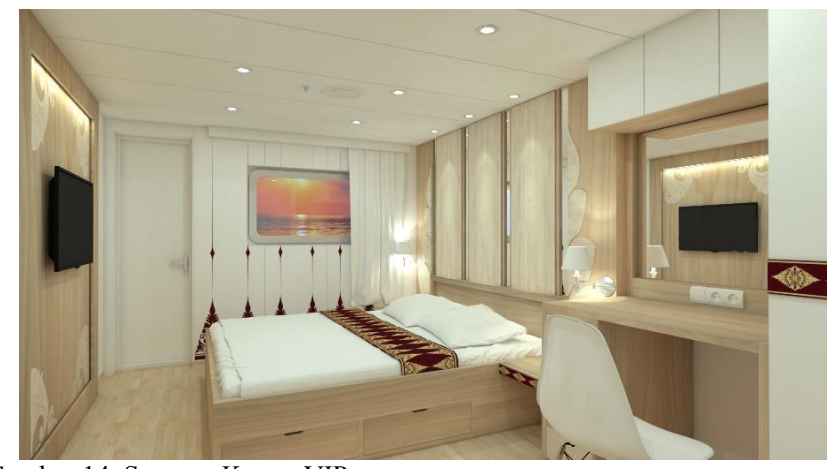

Gambar 14. Suasana Kamar VIP.

Sumber: Dokumentasi Penulis (2018) 
Kamar VIP menggunakan adat Suku Bali sebagai temanya yang dipadukan dengan nuansa hangat ruangan dengan penggunaan material bermotif kayu. Meja kerja pada ruangan ini juga dapat digunakan untuk area rias dengan adanya cermin di depannya.

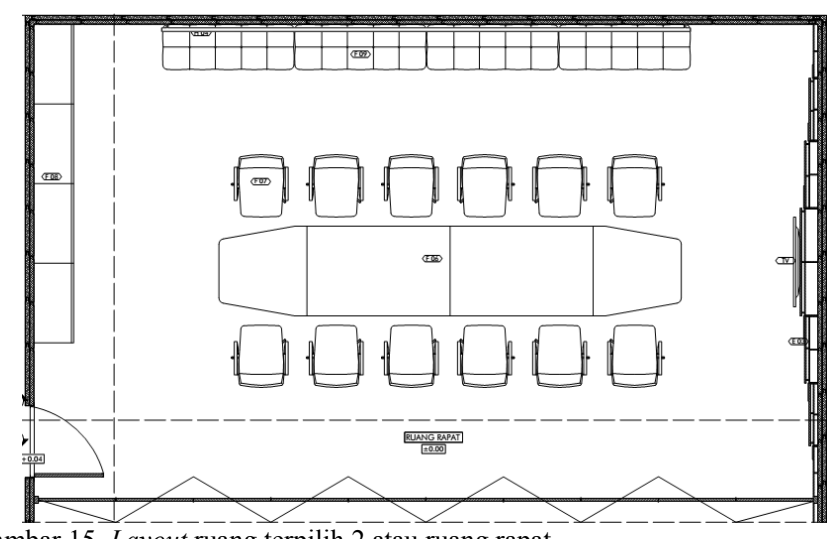

Gambar 15. Layout ruang terpilih 2 atau ruang rapat.

Sumber: Dokumentasi Penulis (2018)

Ruang rapat ini berkapasitas dua puluh orang, dengan dua belas kursi dan dan bench atau bangku berkapasitas delapan orang. Ruang rapat ini memiliki sekat yang dapat dibuka jika memerlukan kapasitas yang lebih banyak. Pemilihan material plafon dan dinding mempunyai material yang sama dengan ruang kamar VIP, akan tetapi di ruang rapat ini terdapat tambahan karpet untuk memperkuat karakter eksekutif ruang.

Suasana ruang rapat ini dipadukan dengan Suku Asmat. Warna biru navy diambil dari salah satu warna kain khas Asmat. Selain itu, warna navy juga identik dengan laut yang Suku Asmat sendiri berdekatan dengan objek wisata Raja Ampat. Pada bagian tengah palfon dan backdrop menggunakan ukiran tameng Suku Asmat. Warna merah pada kursi dan meja dijadikan sebagai aksentuasi pada ruangan ini.

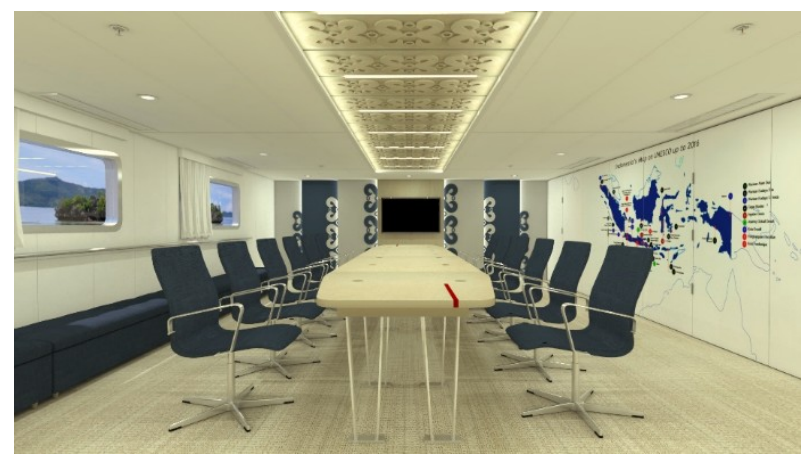

Gambar 16. Suasana ruang rapat.

Sumber: Dokumentasi Penulis (2018)

Bagian sekat atau partisi diberi wallpaper dengan motif peta Unesco Indonesia yang merupakan situs warisan dunia yang berada di Indonesia. Sehingga juga bisa sebagai papan informasi bagi pengunjung.

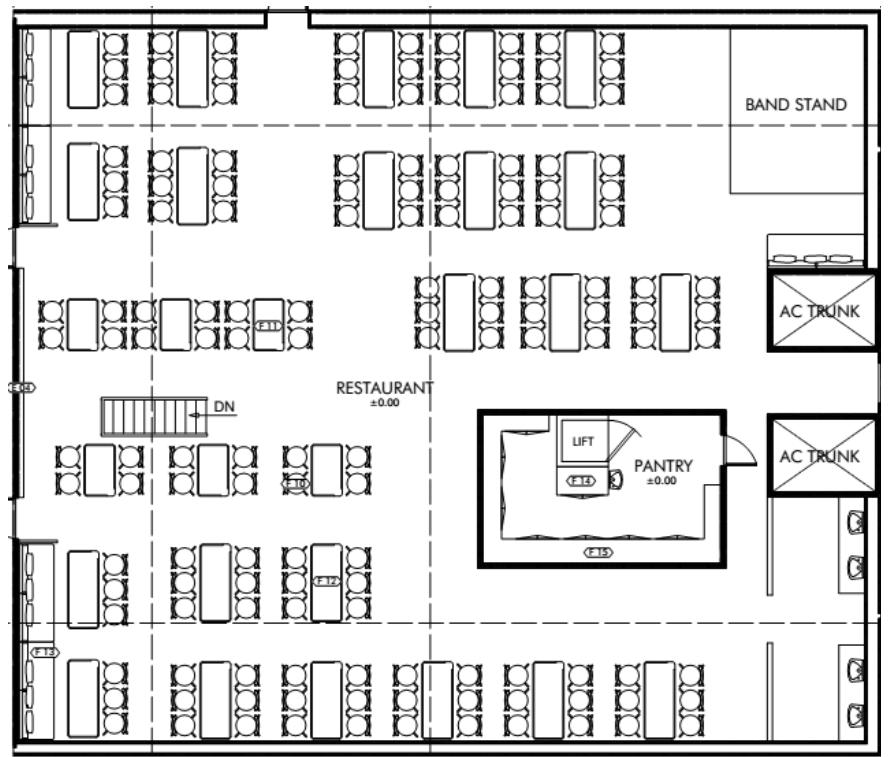

Gambar 17. Layout ruang terpilih 3 atau ruang restoran. Sumber: Dokumentasi Penulis (2018)

Ruang terpilih tiga yaitu merupakan ruang restoran. Restoran memiliki kapasitas 156 orang, sesuai dengan jumlah penumpang pada deck lima.

Restoran memiliki fasilitas stage dan wastafel berjumlah 4 buah. Material plafon dan dinding menggunakan material yang sama dengan kamar VIP dan ruang rapat. Halini dilakukan agar pengguna dapat merasakan transisi pada setiap ruang yang mempunyai fungsi berbeda namun sama dalam konsep dan desain sehingga tidak berdampak pada perubahan ruang yang mempunyai perbedaan yang sangat terasa. Dalam pemilihan materian untuk lantai yang digunakan berupa marine flame retardant $P V C$ flooring dengan motif parket.

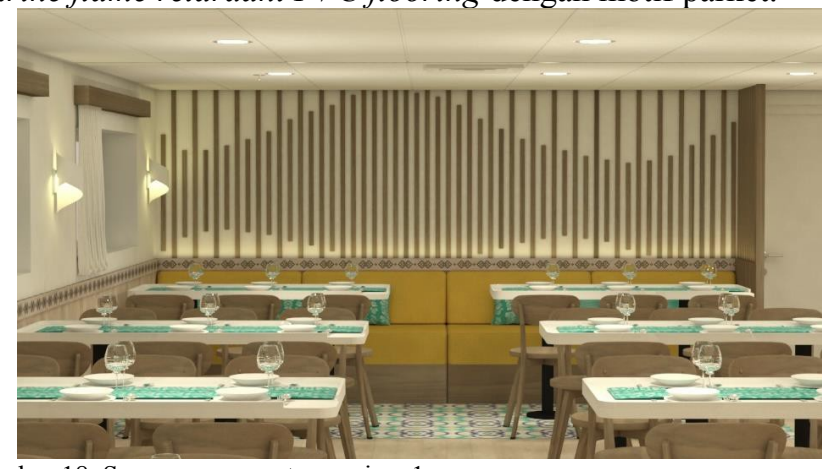

Gambar 18. Suasana area restoran view 1.

Sumber: Dokumentasi Penulis (2018)

Restoran juga menggunakan unsur budaya Papua, khususnya Suku Asmat. Warna kayu yang dominan dan dipadukan dengan warna hijau serta kuning diambil dari kain batik Papua. Pada gambar di atas merupakan spot restoran yang berada di bagian pojok. Pada bagian dinding, terdapat bentukan nirmana dari kayu sebagai aksentuasi. Lantai yang digunkaan berupa HPL dengan motif parket dan HPL dengan motif custom yang disusun dari simbol-simbol khas kebudayaan Asmat. 


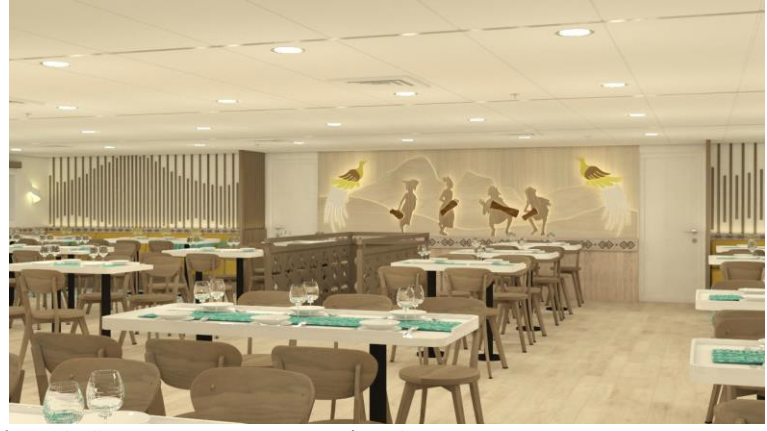

Gambar 19. Suasana area restoran view 2

Sumber: Dokumentasi Penulis (2018)

Pada dinding tengah atau dapat juga diseut dengan main wall karena terdapat panorama dengan tarian siluet Papua serta Cendrawasih untuk memperkuat suasana Papua. Pemberian LED strip di belakang panel panorama membuat semakin menarik dan stand out.

Restoran ini juga memiliki fasilitas hiburan berupa panggung. Pada bagian belakang panggung terdapat dinding yang dipenuhi dengan aksentuasi rotan berpola catur. Selain sebagai pemanis, penambahan rotan pada dinding juga berfungsi sebagai akustik untuk ruangan di belakang panggung.

\section{KESIMPULAN DAN SARAN}

Dari pembahasan Desain Interior KM Kelimutu sebagai Kapal Wisata dengan nuansa Budaya Indonesia timur yang Modern dapat disimpulkan beberapa hal sebagai berikut:

\section{A. Kesimpulan}

1) KM Kalimutu merupakan kapal penumpang yang dijadikan sebagai kapal wisata sehingga dibutuhkan desain interior yang menarik bagi para penumpang.

2) Konsep yang digunakan mengusung budaya Indonesia timur yang dipadukan dengan unsur modern. Pemilihan konsep didasari dengan pemilihan rute kapal.

3) Budaya yang diangkat yaitu budaya Bali dan Papuakhususnya suku Asmat, termasuk didalamya dalam segi kesenian, tarian, motif dan bentukan setiap budaya. Contohnya yaitu bentukan gapura Bali dan tameng suku Asmat.

4) Unsur modern yang diterapkan didalam konsep yaot pengaplikasian atau transformasi dari setiap bentukanbentukan atau motif yang dibuat menjadi lebih sederhana.

\section{B. Saran}

Untuk pengembangan lebih lanjut maka adapun saran yang ingin disampaikan adalah:

1. Penggunaan standar material kapal sangat dianjurkan untuk keamanan kapal.

2. Memperhatikan utilitas pada kapal sehingga perencanaan desain dan layout tidak menyalahi utilitas kapal yang telah ada.

\section{DAFTAR PUSTAKA}

[1] PT Pelni (Persero), "Profil PT Pelni (Persero)," 2018. [Online]. Available: https://www.pelni.co.id/profile.

[2] T. A. Kristianto, "Desain Interior Kapal Navigasi S-126 untuk Meningkatkan Kualitas Keamanan, Kenyamanan, dan Memenuhi Standard Kode yang Berlaku," J. Sains Dan Seni Pomits, vol. 6, no. $2,2017$. 